\title{
Explication of Peculiarities of the Hypergenre in the Text Production of Russian German of Siberia
}

\section{Kostomarov Peter}

Tomsk Polytechnic University

Email: petrkost@yandex.ru

Alexander Ptashkin

Tomsk Polytechnic University

Email: pt.alexandr@gmail.com

Doi:10.5901/mjss.2015.v6n1s1p407

\begin{abstract}
The paper deals with the anthropocentric approach in the context of study of various hypergenre aspects. The aim is to investigate communicative behavior of the linguistic personality and describe its different structural components. Such formulation of the problem provides unstudied conversational analysis of a wide range of recorded language data - talks of the Russian German. One of the main methods is the inclusion of the speaker into the communicative space as a kind of observation. This method is based on psychological long-term sociability between the authors of this paper and the subject. Special emphasis is placed on attention to the variety of micro topics that transmit main content of the hypergenre and show a complex of its lexical and grammatical peculiarities. Received results of this detailed research of various hypergenre aspects contribute to the development of genre analysis. Materials of this article are considered to be useful in German dialectology, the aim of which is to fix and save people's spoken form of the language of the Russian German in Siberia.
\end{abstract}

Keywords: anthropological paradigm, hypergenre, linguistic personality, discourse;

\section{Introduction}

The actuality of the article is determined by an important linguistic and anthropological paradigm of modern science of language, whose task is systematic and multifaceted study of individual human speech. This paradigm is also stipulated by "the increasing role of communicative approach to language, as well as the need to interpret the new speech genres appearing in certain types of discourse" (Dolgova, 2010).

The purpose of the paper is to identify the specific features of the dominant components of the hypergenre "narration about interests" whose author is the representative of the folk spoken form of the German language - Jacob Kondratievich Damm (hereinafter - J.K.) - Russian German born in the Volga region in 1920 and lived most of his life in Siberia.

\section{Research Methodology}

For example, //Interezen have ich immer viel ..., vor allem als ich in Schillink und Zaratow gelevt have, ja, interezant war Garten tsu haven, in Schillink, war interezant, wie der Vaader Gurke, Tomaten, Kartoffel выращивал там, das gefiel mir zehr, war fir uns Garten als tswaites Haus, das Haus, alles war dort zehr schen, Muuder machte alles dort, und wir verzuchten auch tsu helfen, verzuchten tsu machen dort schen, wie ich das Leven schepfe, ich zorkte dafir, verzuchte, чтобы никаких сорняков там не было, чтобы все было чисто. Bruder hatte auch zaine Kulturen im Garten, wir Konkurrents haven, wer hat schneller, wer hat schmeckhaftes. Jettst haven wir auch Gatren, dort steht klain Haus, zehr oft wir frire Take haven, oft im Zommer zehr kalt, nicht kennen wir dort oft haven, nain, das ist zehr schlecht, schlecht fir Garten, frier wir viele Gurken haven, Tomaten zokar, das ist interezant, wenn Ernte gut, viel haven, das ist zehr gut, der Zohn bescheftikt jettst mit Garten zich, mit Garten hat er viele angebaut, Gurken auch, Kartoffel, viele Beere. Wir haven in Schillink zehr viel Tsait, ginken tsu angeln, zelvst machte удилища, das zind zolche grouze Stzve, anfanks konnten wir dariver nichts machen, zelvst machen, Alden halfen uns, aver dann konnten wir zelvst grouze, ginken angeln, finken verschieden Fische, Karpfen, ginken zehr spet, fitterten morken, Fisch клевала так хорошо, gants Eimer brachten nach 
Hauze, brachten viel Fisch nach Hauze, zehr viel, $20 \mathrm{~kg}$, oft kochten wir am Ufer Fischzuppe, dann braten am Faier, dann zazen und azen. In Alexandrowo angelte ich auch, gink mit Bauern auch tsu angeln, сделал себе там тоже большое удилище, mit vielen aus dem Dorf gink tsu angeln, zehr viele Fische haven wir, wollte auch zolch tsu haven, dann brachten zie mir zolches, я с ними тоже помногу был на рыбалке, Frau gezakt, du bist echter Fischer... Телевизор guck ich auch viel ... in der lettsten Tsait Intereze have, Fernzeher zehe ich viel, was tsu machen, kaine Zerie, Wintersport, das war die Winterolympiade, na, in Turin, dort haven unzere Wintersportler zehr gut gespielt, viele Medaille gekriekt, gewonnnen, Журову смотрел на коньках, die zitts jettst in Duma, Sport traive, in Zendunken zehe, часто, Eiskunstlauf gefiil mir zehr auch, zah auch Hockai, unzere haven zehr gut gespielt ... Fussball zehe ich auch, вот, когда наши с Германией играли, sah прямую трансляцию im Fernzehen, unzere haven verloren, gespielt haven wir gut, mit vergniken zah ich чемпионат Европы, dort schniden wir gut ab, wir haven Trainer aus Ausland, spielte Daitschland dort zehr gut, verloren Daitschland im Finale Spanien, Daitschland war vielmals Airopa- und Weltmaister, haven starke Mannschaft zie immer, starke Spieler, которые ... In Schillink haven wir auch zehr Fussball gespielt, wir haven zelvst Ball gemacht, wir mit ihm zehr lanke haven gespielt, viele Tore schoss ich, haven klaine Tore, nai machten, warn starke Mannschaft tswischen Kindr, konnten dort stundenlank spielen, konnten nichts machen, nur spielen//.

The material shows that modeling of verbal behavior, analyzed by linguistic personality, operates not just with individual speech genre expressing a single type of statement, on the contrary, deploying of the move of the communicative process J.K. is trying to formalize his linguistic consciousness using a palette of speech genres, which are identified as "a set of statements united by a common sense orientation, typical for verbal behavior of the speaker, which have situational characteristics and illustrate the behavior of the speaker as an active participant in the communication process" (Kostomarov, Bogoslovskaya, 2012). The complex nature of the identification of range of speech genres as hypergenre sets difficult task to describe the basic components of this unit.

Analyzing structural model of hypergenre, N.V. Denisova argues that "hypergenre is a set of complex speech genres or simple and complex speech genres characterized by unity of goal-setting and text space. The main objective of hypergenre is implemented as a combination of private goals of complex and simple speech types, each speech form performs its function in the overall goal of hypergenre, fixed sequence of genres plays the important role" (Denisova, 2009). The idea of a complex and multi-component structure of hypergenre is continued by B.J. Sharifullin who believes that "speech genres in the communicative space do not exist independently; there are quite complicated relationships among them. Therefore, there is an opportunity and need to talk about the formation of various discourses, whole genre communities (agglomerations). Such communities of different genres (genre "clusters") provide in the framework of single discourse the integrity of one, but daunting text ... Hypergenre, firstly, in contrast to the simple and complex, complex speech genres, reflects not just a "complex" real event, but the event which is divided into different components or episodes, often built in a certain order on a particular scenario" (Sharifulin, 2012). O.A. Kazakova expresses an interesting opinion about criteria for analyzing of hypergenre in the speech production of representative of folk culture, which include distinguished "communicative purpose, type of communicative situation, the repertoire of simple and complex genres tactics of verbal behavior" (Kazakova, 2007).

In our opinion, one of the most important conditions for the functioning of any hypergenre is the image of its author. The author of investigated hypergenre "narration about interests" is ordinary linguistic personality that "acts pragmatically in defined role or roles creating a text of a particular genre - in such that this kind of text requires" (Budagov, 1974). Individual author beginning sets the tone in the process of creation and deployment of texts of various thematic confinement. As M.M. Bachtin marks, the image of the author is considered as the dominant feature of any speech genre as "depicting beginning" (Bachtin, 1979). The material shows that the personality of the author in the context of hypergenre reflects the model of verbal interaction, organizing units which are:

a) logical and coherent construction of narration, characterized by internal structural relatedness of chain of sentences, as well as their targeted syntactic communication needed to plexus of pieces into whole speech work;

b) taking into account the pragmatic side, which is to create strategies of communicative interaction and focusing effects on the target trajectory on addressee from the side of the author.

Drawing attention to the bright and distinctive personality of the author also makes a detailed approach to the identification of the role of the addressee in the study of hypergenre reflecting in the text production of J.K. The addressee who is represented as an important participant in the communication process is also a fundamental representative and "reflector" of linguistic consciousness of the speaker through the postulated texts. It should be noted that verbal behavior of the language personality focuses on communicative dialogue with the addressee of the text, which from the point of pragmatism is understood as "a stable set of perceptions and cognitive structures that coordinate and regulate the text behavior and of the author of the text" (Kaminskaya, 2009). Communicative contact of the speaker and 
the listener assumes the character of a confidential conversation, understood as "a specific genre uniting phatic and information communication in equally manner, as the direct transfer of information combined with a pleasant time spending, pleasure, and the presence of a component of "information" in the name of semantics allows to talk about the importance of information in the beginning of the structure of the genre" (Laguta, 2009). Tactics of the conversation in the context of the deployment of the hypergenre "narration about interests" is aimed at creating a favorable atmosphere between the author and the addressee. The addressee is often presented as a personality who has a comparable social status with the speaker. This method of communication provides a factor of rapprochement of informant as an active participant of speech production with the listener, whose main function is adequate perception of received information.

Of course, an important criteria for the establishment and "movement" of a certain hypergenre is its communicative purpose. Considering hypergenre "narration about interests" we point out determinacy of communicative intent of the informant, which "is a common, integrative starting point for any and all speech genres" (Gorelov, 2003). As part of the deployment of the conversation a communicative goal becomes direction vector defining and regulating the communicative behavior of communication. Such a chain of representation of hypergenre raises the question of the formation and use of the tactics of verbal behavior from the side of informant considered in the unity of the four major components of the "situation - author - text - recipient". Communicative strategy incorporates a given motive, the thrust and intent of statements that implement successful completion of the act of communication. According to N.I. Formanovskaya, "as opposed to desire, which is an appetence, an affection is to implement something, the plan shall be construed as conceived plan of action, so it seems appropriate to associate primarily with the intention of conception; speech intention is intention, the intention to do something, to take action with the help of a tool such as a language speech - statement that carry out the speech act" (Formanovskaya, 1998).

\section{Findings and Discussion}

The analysis of text production of J.K. illustrates the fact that one of the signs of hypergenre "narration about interests" is reflection of the dictum content transmitting basic micro-topics in the hypergenre. In the structure of the hypergenre "narration about interests" we observe explication of three micro-topics forming hypergenre. These micro-topics are "garden", "fishing" and "sport".

Micro-topic "garden" which refers to the cultivation of vegetable crops and horticulture in general is understood by the informant as an integral, important component of mental life of a representative of folk culture, a certain part of life spent in the village. The narrative in the context of this micro-topic is modeled by J.K. due to the coverage of a number of crops that are planted by the mother of the speaker (cucumbers, tomatoes, potatoes). An important part of the story about the process of growing crops is selection of category "garden" identified by J.K. as a "second home" which plays an important unifying role for consciousness of the villagers. In other words, in the mind of J.K. "garden" is a complex multilevel image having historical roots of its development and the importance for members of rural culture.

Micro-topic "fishing" is also one of the main structural elements of hypergenre "narration about interests". The material shows that fishing was a favorite time spending of the peasants in the village of Schilling, where this craft united representative of older and younger generations. It should be noted that the postulation of hypergenre occurs with typical concretization of fishing's peculiarities. This approach to the detailed description of this process suggests that fishing occupied an important place in the context of the life continuum of representatives of the traditional family of the Russian Germans. J.K. paints a picture characterized by the complexity of manufacture of rod for successful fishing, help in this process from the side of adults, as well as different kinds of fish catching and cooking fish soup.

The actualization in the structure of hypergenre micro-topic "sport" concerning the will of the informant to watch sports programs and references to sports in the childhood speaks to the significant side of this type of activity positioning the speaker as an active linguistic personality. Sports component of hypergenre unfolds mainly on supplying background information about winter sports (hockey, figure skating) in the context of the Olympic Winter Games in Turin in 2006, as well as the elucidation of the problems of football connected with the successful performance of the Russian national team during European Championships in 2008. Additional markedness of football in life happens due focusing on the childhood years when J.K. was keen on playing football with the other children.

The factor of communicative time plays an important role in identifying of hypergenre considered as the time interval between the creation of the text and its perception. Communicative time is explicated in hypergenre due to two major temporary forms which are specific for this hypergenre. These include the forms of the past and present of the German language.

Verb form of present tense is typical for actions that take place at a given time. A striking example of the use of the present tense of the German language is the description of the situation related to the work in the garden, in which 
agricultural crops are grown. //Jettst haven wir auch Gatren, dort steht klain Haus, zehr oft wir frire Take haven, oft im Zommer zehr kalt, nicht kennen wir dort oft haven, nain, das ist zehr schlecht, schlecht fir Garten, frier wir viele Gurken haven, Tomaten zokar, das ist interezant, wenn Ernte gut, viel haven, das ist zehr gut/. The speaker, in addition to instructions on crops, postulates a statement about a successful harvest //wenn Ernte gut, viel haven, das ist zehr gut//. An interesting point is analysis of the forms of the present tense in the context of reflection of facts related to fishing. Verbs of present tense are now particularly evident in cases where the informant wants to emphasize the importance of this effect in the general postulation of mikro-topic "fishing". This characteristic concerns: 1) the name of his native village, where J.K. was keen on fishing /Wir haven in Schillink zehr viel Tsait/; 2) draw attention to the ways of cooking fish //braten am Faier//; 3) mention tools of fishing //das zind zolche grouze Stzve//; 4) amount of catch //zehr viele Fische haven wir//, 5) identify positive feedback from others in learning abilities of fisherman //du bist echter Fischer//.

Temporal characteristics of speech, explicable in the present tense, is implemented in the micro-topic "sport" as a part of hypergenre "narration about interests". On the one hand, the analysis of the hypergenre shows that present tense currently shows the frequency and the speaker's personal interest in watching sports telecasts //in der lettsten Tsait Intereze have, Fernzeher zehe ich viel//, in Zendunken zehe, yacmo//, on the other hand, draws attention to actualization in the communicative process names of Russian athletes, in particular, Svetlana Zhurova, who occupies a responsible position in the State Duma //die zitts jettst in Duma//. In the structure of micro-topic "sport" we find football problems disclosed on the background of the reflection of the time in the description of the activities of the foreign expert as head coach of the Russian national team, whose name is linked to the main team's success during European Championships //wir haven Trainer aus Ausland//. The informant also recollects problems associated with the lack of necessary equipment for this sport in his native village of Schilling //haven klaine Tore//.

To deploy a temporal perspective of micro-topic "garden", which is composed of verbal behavior based on the use of verb forms of the past tense, the informant wants to show circle of close relatives, especially his mother and father, who have given much time and effort in the work garden //vor allem als ich in Schillink und Zaratow gelevt have, ja, interezant war Garten tsu haven, in Schillink, war interezant, wie der Vaader Gurke, Tomaten, Kartoffel выращивал там, das gefiel mir zehr, war fir uns Garten als tswaites Haus, das Haus, alles war dort zehr schen, Muuder machte alles dort, und wir verzuchten auch tsu helfen, verzuchten tsu machen dort schen, wie ich das Leven schepfe//. The brother is also referred in the discourse of J.K. who was engaged in planting of culture in the garden //Bruder hatte auch zaine Kulturen im Garten//. Schematic side of reflection of mikro-topic "garden" transmitting forms of the past tense is the personality of the speaker, who always respondes to help a mother in setting up and maintaining garden //ich zorkte dafir, verzuchte, чтобы никаких сорняков там не было, чтобы все было чисто//. The peculiarity of his contribution to the "prosperity" of the garden is punctuated by changing the code of the narrative combining the use of the past tense forms of both Russian and German languages. It seems that the transition from one language to another is an individual position of J.K. in identifying his significance for the speaker himself, with respect to the role of work in the garden.

A distinctive charactiristic of the past tense by disclosing of mikro-topic "fishing" in hypergenre is not only a detailed description of a thorough preparation for the fishing //anfanks konnten wir dariver nichts machen//, //ginken tsu angeln, zelvst machte удилища//, //ginken zehr spet, fitterten morken, Fisch клевала так хорошо//, but also references to number of persons with whom the speaker was engaged in fishing //Alden halfen uns//, //gink mit Bauern auch tsu angeln//, //mit vielen aus dem Dorf gink tsu angeln//, //я с ними тоже помногу был на рыбалке//, and commenting on the amount of fish caught //gants Eimer brachten nach Hauze, brachten viel Fisch nach Hauze, zehr viel, $20 \mathrm{~kg} / /$, as well as and the name of the dish cooked from fish //oft kochten wir am Ufer Fischzuppe//.

The transfer of past tense in mikro-topic "sport" focuses primarily on Winter Olympics, held in 2006 in italian city of Turin /Wintersport, das war die Winterolympiade, na, in Turin//. Informant gives commentary on the level of performance of the Russian athletes in winter sports (hockey, figure skating and skates) and winning medals //dort haven unzere Wintersportler zehr gut gespielt, viele Medaille gekriekt, gewonnnen//, IIEiskunstlauf gefiil mir zehr auch, zah auch Hockai, unzere haven zehr gut gespielt//. Main characteristic of reflection of events in the context of mikro-topic "sport" with the past tense is to focus attention on the speaker's opposition between Russian and German football team //kozda наши с Германией играли, sah прямую трансляцию im Fernzehen, unzere haven verloren, gespielt haven wir gut, mit vergniken zah ісһ чемпионат Европы, dort schniden wir gut ab//. On the one hand, this description reflects the failure of the German national team in the final of the European Championships in 2008 //spielte Daitschland dort zehr gut, verloren Daitschland im Finale Spanien//, on the other hand, it isolates numerous titles of this country, both at European and on the world stage //Daitschland war vielmals Airopa- und Weltmaister/l. The process of explication of football perspective is projected on personality of J.K. who was keen on football which united children in village of Schilling //In Schillink haven wir auch zehr Fussball gespielt, wir haven zelvst Ball gemacht, wir mit ihm zehr lanke haven gespielt, viele Tore schoss ich//, I/nai machten, warn starke Mannschaft tswischen Kindr, konnten dort stundenlank spielen, 
konnten nichts machen, nur spielen//.

\section{Concluding Remarks}

To summarize, after analyzing of the most important components in the context of text production of representative of popular culture we can say that hypergenre "narration about interests" as a special type of speech can be considered as multi-voice work, which has focusing multidisciplinary vector of reflection of reality in the linguistic consciousness of the speaker and has impact on the addressee, as well as number of dominant characteristics which are necessary for the explication of the temporal and linguistic architectonics.

\section{References}

Bachtin, M.M. (1979). The aesthetics of verbal creation. Moscow: Arts.

Budagov, R.A. (1974). Man and his language. Moscow: University Press.

Denisova, N.V. (2009). Genre organization of university's booklets. Language and Culture, 1(5), 12-21.

Dolgova, E.V. (2010). Discursive and communicative features of speech genre "businessman's portrait" (based on the Russian and English languages). Moscow, University Press.

Formanovskaya, N.I. (1998). Communicative and pragmatic aspects of communication units. Moscow: Institute of Russian. Language of Alexander Pushkin.

Gorelov, I.N. (2003). Selected works on psycholinguistics. Moscow: Labyrinth.

Kazakova, O.A. (2007). Dialectal linguistic personality in the genre aspect. Tomsk: University Press.

Kaminskaya, T.L. (2009). The image of the addressee in the texts of mass communication: semantic-pragmatic research. St. Petersburg, University Press.

Kostomarov P.I., Bogoslovskaya, Z.M. (2012). Text in the individual variant of the German folk speech of Siberia. Tomsk: University Press.

Laguta, N.V. (2009). Genre space of one conversation. Word: Folklore dialectological almanac, 7, $105-110$.

Sharifullin, B.J. (2012). Hypergenre and hypergenre scripts in verbal and nonverbal communication. Humanities and Social Sciences, 6 , 132-144. 